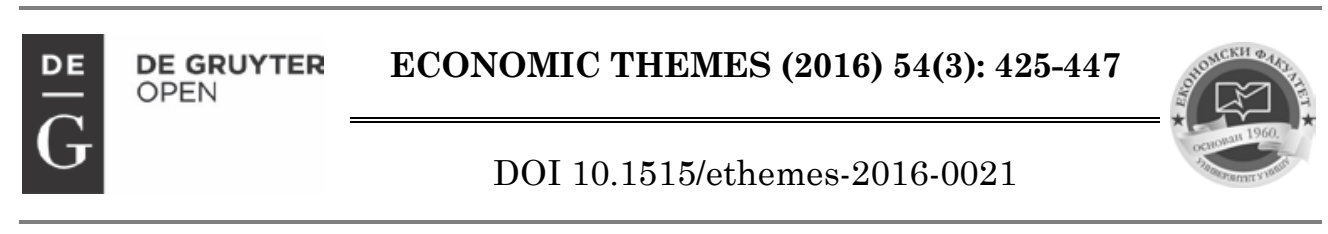

\title{
ACCOUNTING REGULATION OF FINANCIAL REPORTING BY SMALL AND MEDIUM-SIZED ENTITIES WITH NO PUBLIC ACCOUNTABILITY
}

\author{
Tanja Škobić
}

\author{
Independent advisor-auditor at State Audit Institution, Belgrade, Republic \\ of Serbia \\ State Audit Institution, Belgrade, Republic of Serbia \\ $\bowtie$ tanjaskobic@yahoo.com
}

UDC
675
Review
paper

Received: 21.01.2016. Accepted: 03.10.2016.

\begin{abstract}
The establishement of uniform rules and principles for the recognition and evaluation, requirements for presentation and disclosure of elements of the financial statements provides global comparability, harmonisation and high quality financial reporting. Taking into account the simpler requirements of small and mediumsized entities in relation to large entities, the International Accounting Standards Board (IASB) has created a financial reporting standard to meet the needs and capabilities of small and medium-sized entities with no public accountability, which, although the reduced volume and simplified requirements, does not diminish the quality or transparency of financial reporting. The author aims to point to the justification of the need to establish a standard for medium and small entities, analyzes its basic characteristics and examines the relations with full standards and EU regulations. Mandatory application of the standard for small and medium entities in the Republic of Serbia is justified, but other conditions are also required for its successful implementation, which are not provided due to the alternative use of national legislation that is incomplete and vague, and inconsistent with the standards, concludes the author.
\end{abstract}

Keywords: financial reporting, IFRS for SMEs, quality of financial reporting, accounting regulations, small and medium size entities.

JEL classification: M41; M48

\section{Introduction}

After a successful adoption and implementation of International Accounting Standards / International Financial Reporting Standards (IAS / IFRS), which 
are also called full or large-scale standards, the creators of standardization instruments in financial reporting have continued to create, adopt, publicise and apply the unified International Financial Reporting Standard for Small and Medium-sized Entities (IFRS for SMEs), as a logical follow-up and response to the differing needs of the beneficiaries of financial reporting for small and medium-sized companies without public accountability. As a matter of fact, the above indicated entities have simpler requirements and different circle of beneficiaries with limited needs for information in comparison to beneficiaries of financial information of publicly accountable companies and organizations, that is to say large-sized entities, and in particular multinational companies.

IFRS for SMEs is the standard on financial reporting which is consistent with large-scale IAS/IFRS, except that it is being adjusted to small and medium-sized entities in terms of complexity, intelligibility and facilitated application, and primarily in terms of requirements determined by their business activities.

Small and medium-sized entities in the Republic of Serbia are implementing, beginning with 2004, so-called large-scale IAS/IFRS as a conceptual framework for reporting, which could lead to a conclusion that it required enormous investments by above-mentioned entities. International Financial Reporting Standard for Small and Medium-sized Entities ${ }^{1}$ adoption and implementation causes a qualitative change in entities which are about to implement it while preparing, presenting and disclosing financial statements , as well as beneficiaries of financial statements of the named entities.

\section{A Need to Establish Accounting Standard for Financial Reporting in Small and Medium-sized Entities with no Public Accountability}

International Financial Reporting Standards volume and complexity are the consequence of large number of transactions and business changes in increasingly complex business operations of large, globally oriented entities, which place high but unnecessary requirements upon small and medium-sized entities, considering that they are handling modest equity and simpler business operations, as well as employing less personnel, and that very often managerial and ownership structure are divided, so that in these cases large number of investors lack interest since some of them are already participating in management and are therefore in possession of all the information needed

1 The Resolution of the minister of finance on determining translations of IFRS for SMEs employs the term: for small and medium-sized legal entities, while the official translation of the title of the standard is the International Financial Reporting Standard for Small and Medium Entities. 
(Škarić, 2011).

Suppliers, customers, banks, state and employees are the main interested sides of financial statements. That leads to a conclusion that smaller number of beneficiaries are interested in financial statements, that is financial position, performances and cash flows of small and medium-sized entities, so that their need for information is minor to the needs of beneficiaries of financial statements of publicly accountable, large-sized entities, and particularly multinational companies.

The large-scale IAS/IFRS implementation by small and medium-sized entities by any means can be considered erroneous; on the contrary, financial statements created on the basis indicated above meet the requirements regarding quality of financial reporting. However, complex requirements and principles of measurement and disclosure could motivate a consistent growth in costs of financial reporting, in terms of investing into professional accountants education, amendments of the existing accounting informational systems and more, due to the changes to the standards.

Given the above, after long-term deliberation of the International Accounting Standards Board, the International Financial Reporting Standard for Small and Medium-sized Entities is adopted and published in July 2009, altogether with the follow-up material: Basis for Conclusions and Illustrative Examples of Financial Statements and Compliance Checklist for Presentation and Disclosure (IASB, 2010).

A need to adopt and implement IFRS for SMEs in the Republic of Serbia is illustrated by the following facts:

a) IFRS for SMEs adoption enables significant savings for economy, given that large-scale standards are implemented beginning with 2004;

It is important to highlight that the large-scale standards in the Republic of Serbia have been implemented since 2004, which means that professional accountants are qualified for their implementation, given that the International Financial Reporting Standard for Small and Medium-sized Entities is simplified and adjusted to small and medium-sized entities. A significant economic saving is accomplished in that way, by reducing costs of training and creating favourable conditions for implementation of IFRS for SMEs.

The Centre for Strategy \& Evaluation Services has, within the research conducted by the European Union authorities, performed an analysis on the subject of implementation of IFRS for SMEs as the financial reporting basis. In the context of saving, that is to say spending cash assets on creation and presentation of financial statements on the basis of IFRS for SMEs, upon adoption, highlighting the following results, bearing in mind optimal administrative costs for totally 325 companies covered by the analysis (The 
Centre for Strategy \& Evaluation Services, 2010).

Table 1 The Amount of Weighted Savings for the Economy on the Basis of IFRS for SMEs

\begin{tabular}{|c|c|c|c|c|c|}
\hline \multirow{3}{*}{$\begin{array}{c}\text { Entity } \\
\text { size } \\
\text { Large }\end{array}$} & \multirow{3}{*}{\begin{tabular}{|}
$\begin{array}{c}\text { Administrative } \\
\text { costs } \\
\text { in million } €\end{array}$ \\
578
\end{tabular}} & \multicolumn{2}{|c|}{$\begin{array}{l}\text { Presentation of Financial } \\
\text { Statements on the basis of } \\
\text { IFRS for SMEs }\end{array}$} & \multirow{2}{*}{\multicolumn{2}{|c|}{$\begin{array}{l}\text { Explanatory Notes of } \\
\text { Financial Statements on } \\
\text { the basis of IFRS for } \\
\text { SMEs }\end{array}$}} \\
\hline & & $\begin{array}{l}\text { Savings in } \\
\text { million } €\end{array}$ & Savings in \% & & \\
\hline & & 2 & 0 & Large & 578 \\
\hline Middle & 429 & 9 & 2 & Middle & 429 \\
\hline Small & 3.015 & 31 & 1 & Small & 3.015 \\
\hline Micro & 5.439 & (10) & 0 & Micro & 5.439 \\
\hline
\end{tabular}

Source: Centre for Strategy and Evaluation Services, 2010, p. 38

b) Improved quality of financial reporting as well as the possibilities of investments

Adoption of IFRS for SMEs as the basis of financial reporting in the Republic of Serbia should lead to improvement of quality of financial reporting, transparency of financial statements for all stakeholders - the state, investors, banks, business partners, employees and others - and thus to creating a favourable climate for investments (PWC, 2009).

c) Globally accepted harmonisation activities and enhancement of the quality of financial reporting

Global acceptance of the so-called large-scale standards in the European Union, as well as worldwide, has confirmed a need for global harmonisation of financial reporting. A logical sequel of this global initiative is in the progress, throughout adoption of the implementation of IFRS for SMEs, which happen to be the activity strongly supported by international organizations such as IFAC (International Federation of Accountants), World Bank, IMF, USAID and so on.

d) Adopting IFRS for SMEs is a logical sequel of the global acceptance of the large-scale standards within the European Union, as well as worldwide

Currently, about 80 countries require or allow implementation of IFRS for SMEs, while the European Commission is considering introduction of mandatory application of IFRS for SMEs, whereby 19 out of 29 members expressed positive attitude about the said issue, and others accepted their adoption with certain remarks. The standard is officially translated and available in 28 languages (IFRS Foundation, 2014). 
Considering the Republic of Serbia`s focus on the European Union and a willingness or a need for attracting investors and strengthening stability and security of an economic environment, adoption of IFRS for SMEs implementation seems to be a logical choice.

\section{e) Continuous procedure of harmonisation with the European Directives}

The differences between the European Directives and International Financial Reporting Standard for Small and Medium-sized Entities could be eliminated by modification of the Directives as well as of the Standard, which is a work in progress (EFRAG, 2015), which the further subtitle is going to be about.

Considering the need to attract foreign investors and to strengthen stability and security of an economic system in the Republic of Serbia, as well as a focus of the Republic on the European Union, an ambiguity regarding introduction and implementation of the International Financial Reporting Standard for Small and Medium-sized Entities is hard to understand and preferably should not exist.

However, since all IAS / IFRS, as well as the rest of the standards, constitute an international professional accounting regulation, a favourable regulatory environment appropriate for their application is of utmost importance, in terms of adequate legitimate regulations.

Generally speaking, appropriate legitimate regulations should be enacted by competent ministeries in order to settle primarily financial reporting system for the public and private sector, while accepting global instruments, rules and procedures of the creators of such global financial reporting instruments, including financial reporting by small and medium-sized entities on the basis of IFRS for SMEs, with the participation as well as the responsability of the accounting profession members in creating financial statements, since the state is to be responsible for the creation of favourable environment for economic activities of all business entities.

Despite the above-mentioned reasons for adoption, the current legislature has not adequately regulated the implementation of IFRS for SMEs, nor professional regulations generally, which remains a constraining factor in achieving the standardization of financial reporting in the Republic of Serbia.

According to the new Law on Accounting (Official Gazette of Republic of Serbia, No. 62/2013), medium-sized entities are allowed the possibility to choose among IFRS for SMEs or IAS / IFRS, small legal entities apply IFRS for SMEs, while micro entities and other legal entities are also allowed to chose the Rule book adopted by the minister of finance, with the creation of smallscale set of financial statements. IFRS for SMEs, according to the transitional provisions of the Law on Accounting, apply to the financial statements which 
are prepared on December 31, 2014.

It is important to note that the cooperation between the state and professional organizations has a key role in establishing a foundation in terms of regulation applying to the first time adoption of IFRS for SMEs, as well as to provide a necessary assistance to the professional accountants who are going to implement these standards in practice (Stojanović, 2016). A national professional organizations which are the members of IFAC are binded, considering the scope of their membership responsibilities, to provide necessary support to the implementation of IFRS for SMEs (Serbian Association of Accountants and Auditors is a professional organization, member of IFAC http://www.ifac.org/about-ifac/membership/members).

International Accounting Standards Board, as well as the European Union are willing to offer a necessary sustain to their members in the process of acceptance and application of IFRS for SMEs, which is essential (European Commission, 2010). Likewise, economic entities who prepare their financial statements on the basis of IFRS for SMEs have a distinguished role within the initiative for adoption and implementation of IFRS for SMEs, considering that, after all, these standards are set up for them. Small and medium-sized entities management and employees should understand their interest for the application of IFRS for SMEs and therefore actively support the initiative for their adoption and application since it would, most probably, significantly reduce financial reporting costs (Alver et al., 2014).

Considering all of the above mentioned main points, it is able to draw a conclusion that the following organizations are in charge for the adoption and application of the IFRS for SMEs: the state and its competent authorities ministry, professional organizations - IFAC members, as well as business communities (Union of Employers of the Republic of Serbia and other business associations) which are supposed to apply directly the standards and thereby achieve some immediate benefit. A mutual cooperation and sustain among all of the sides involved would enable achieving the desired result, and thus harmonisation, transparency and high level of financial reporting quality, as well.

By contrast, a creation and introduction of a national standards, which would promote some groups of interest, would be the primary cause of high costs of working groups in charge of creation of these standards; besides, it would enable leaving fair and objective reporting frame, due to causing certain type of atmosphere conductive to subjective interpretation of their implementation, which would largely cause mistrust of the potential investors, since such financial statements would, in any case, be justifiably qualified as financial statements prepared in accordance with international professional regulation. Likewise, the question is are there any possibilities of taking over 
the text of official translation of the International Financial Reporting Standard for Small and Medium-sized Entities and representing the text as some kind of a national standard, since the text of the standard is a subject to copyright.

In this regard, an example of an attempt that has failed includes creation of the Rulebook on the manner in which assets, obligations, revenues and expenses of small legal entities and entrepreneurs are recognised and measured (Republic of Yugoslavia Official Journal, No. 71/02 and RS Official Gazette, No. 106/2006 and 111/2006) which became applicable in 2006. The above mentioned Rulebook partly relies on the international standards, which again requires knowledge of the same by potential beneficiaries of the Rulebook, as well as on the national practice and as such it is neither applicable, nor practically applied, since its application is proscribed for until the end of 2015. In 2013, based on the current Law on Accounting, there has been adopted a new Rulebook on manner in which items of individual financial statements of microsized and other legal entities are recognised, measured, presented and disclosed (Official Gazette of Republic of Serbia, No. 118/2013, 95/2014), which regulates similar issues but, however, it is neither widely applied, since it relies on the very standard which is willingly accepted by professional accountants in the domestic practice.

The new Law on Accounting (2013) provides opportunities of choice to micro-sized legal entities (which, according to data provided by the Agency on Commercial Register, make for about $90 \%$ of reporting entities) between the Rulebook enacted by the minister of finance and IFRS for SMEs.

The Rulebook enacted by the minister consists of rules on recognition, measurement, presentation and disclosure of items in financial statements of micro-sized legal entities. The previous Rulebook on the manner in which assets, obbligations, revenues and expenses of small legal entities and entrepreneurs are recognised and measured, above mentioned, can be applied no later than December 31, 2015, while IFRS for SMEs is applicable on financial statements prepared on December 31, 2014. (Law on Accounting, 2013).

A phase of adjustment is a logical consequence of a transition from IAS / IFRS to IFRS for SMEs as the basis of financial reporting by small and medium-sized entities. The training of professional accountants responsible for the preparation of financial statements, presenting new regulation to a management, which often requires amendments of accounting policies and / or other internal rulebooks, as well as changes in accounting informational systems including technical modifications and adjustments of an organization at all levels to the new (but not significantly different) concept of financialaccounting business operations, are all the changes that will inevitably take place. 
However, the largest changes refer not to technical differences, but to consequences of these differences. Namely, a different manner of evaluation, of recognition as well as a different classification will cause changes in the manner of statement of income and expenses, as for assets and liabilities. This difference does not have equal effect on any reporting entity, but is extremely important to highlight that the difference is caused by the changes in the basis for financial reporting, which is adjusted particularly to these reporting entities and therefore has no effect on reliability and benefits gained by the information presented in financial statements, and peculiarly has no negative effect on quality of financial reporting by small and medium-sized entities.

\section{Characteristics of the International Financial Reporting Standard for Small and Medium-sized Entities with no public accountability}

IFRS for SMEs Draft Proposal has been published for the first time and was a subject to open discussion which took place in February 2007, where a Serbian Association of Accountants and Auditors (SAAA) took part, as a professional organization, member of the International Federation of Accountants (IFAC).

After intense deliberation on proposals, comments and suggestions, a final version of the Standard has been adopted and published in 2009 (IASB, 2009). The Standard has been translated into Serbian language and published by the Serbian Association of Accountants and Auditors, as a full-member of IFAC ${ }^{2}$, (IFAC members: www.ifac.org/about-ifac/membership/members/ as at 02/2016.) designed for the entire territory of Serbia, Montenegro and Bosnia and Herzegovina.

Upon adoption of IFRS for SMEs (which was adopted by 13 out of 14 members of the International Accounting Standards Board) a promotional event for this standard for the Serbian language speaking area (including Serbia, Montenegro and Bosnia and Herzegovina) was organized in Belgrade by the member of International Accounting Standards Board, and one of the creators of IFRS for SMEs, Mr. Paul Pacter.

IFRS for SMEs is a completely independent document, which means that entities which apply it are not binded to use the large-scale IAS / IFRS. The International Financial Reporting Standard for Small and Medium-sized

2 After completed translation of the entire set, consisting of: International Financial Reporting Standard for Small and Medium-Sized Entities, Basis for Conclusions, Illustrative Examples of Financial Reports and Compliance Checklist for Presentation and Disclosure, a presentation of the Standard, as well as a professional training of accountants, have been organized by the Serbian Association of Accountants and Auditors. 
Entities is designed for small and medium-sized entities (IASB, 2009) which:

- Have no public accountability;

- Disclose financial statements of general purpose designed for the external beneficiaries and

- Have small-sized volume and relatively simple business operations.

IFRS for SMEs can as well be implemented by dependent entities, in case of related parties, provided that these dependent entities have no public accountability, although a parent entity or a consolidated group use complete set of IAS / IFRS, on the basis of which IFRS for SMEs is created.

IFRS for SMEs was created by taking over basic concepts from the Framework and principles and related obligatory guidelines of the large-scale IFRS, aside from changes in order to adapt to the needs of a certain group of beneficiaries and taking into consideration a costs / benefits analysis.

An entity which prepares financial statements in accordance with standards of general purpose has to choose a basis for the preparation, in terms of a complete set of large-scale standards, as for the IFRS for SMEs, which means that there is no option to apply individual principles or standards simultaneously with IFRS for SMEs. Otherwise, above mentioned would cause impaired comparability of financial statements and on the other hand limitless choice of accounting policies, as for options to choose.

Financial statements prepared on the basis of the IFRS for SMEs should provide clear information on financial position, performances and cash flows in order to meet requirements of the beneficiaries. Information contained in such financial statements should be characterized by intelligibility, relevancy, reliability, completeness, timeliness, balanced costs and benefits as well as other characteristics.

It is considered that an entity which prepares and presents financial statements in accordance with all the requirements of IFRS for SMEs provides a true insight into its financial position, financial performances and cash flows and such a compatibility should be proclaimed in the Disclosure Notes on Financial Statements.

A period of adjustment to IFRS for SMEs, unlike IAS / IFRS, is estimated at three years, except that it is not a rigid time frame but a projected deadline, because in case there was a need to amend IFRS for SMEs in relationship to a certain question, it could be deliberated even earlier. A period between disclosure of amendments and their effective date is estimated to be one year. Time frame of amendments to standards is considered important, because it establishes a distinction between IFRS for SMEs and very dinamic IAS / IFRS, which requires continuous training investments as for tracking above mentioned 
amendments by the professional accountants, which more often than not are not negligible for small and medium-sized entities.

The initial amendments to the IFRS for SMEs (issued in 2009), were amendments published in May 2015, which replaced 21 out of totally 35 sections of IFRS for SMEs. Effective date of the above-mentioned amendments is January $1^{\text {st }}$, 2017, with the possibility of earlier application (IASB, 2015).

The initial Standard amendments were classified by the Board as follows (IASB, 2015, p. 25):

- 3 significant amendments;

- 12 insignificant amendments that is to say explanations emerged as a result of new or revised IAS / IFRS;

- 7 new exemptions from IFRS for SMEs requirements, which are tolerated only in particular cases;

- 6 other amendments to requirements for recognition and measurement;

- 6 other amendments to requirements for presentation and disclosure and

- minor changes or explanations of guidelines, which are not expected to affect former practice.

The most significant amendments to the Standards (IASB, 2015) (3 significant amendments) are those refering to:

1) Section 17 - Property, plant and equipment, by which a model of revalorization, as an option of additional evaluation of property, plants and equipment, is allowed;

2) Section 29 - Income tax, where requirements regarding recognition and measurement of deferred income tax are in line with the requirements in IAS 12 - Income tax. Planned amendments to IAS 12, to which the Section 29 Income tax of the initial IFRS for SMEs is based upon, still haven 't been adopted, so it is necessary to harmonize the two above indicated standards. By amendment introduced in 2015, Section 29 has been harmonized with the basic principles of IAS 12, including recognition and measurement of deferred taxes, as well as exemptions due to unjustified costs and efforts regarding requirements for the tax-based compensation of assets and liabilities.

3) Section 34 - Specialised Activities - requirements for a recognition and measurement of researches and evaluations (of this type) of property are in line with the IFRS 6 - Exploration for and Evaluation of Mineral Resources. 


\section{Relationship between the International Financial Reporting Standards for Small and Medium-sized Entities and the full-scale Standards}

IFRS for SMEs are based upon key principles of the IAS / IFRS, which actually was the main purpose of their adoption. The goal to be achieved by creating standards tailor-made to small and medium-sized entities was simpler, easier application as compared to IAS / IFRS, as well as presentation of information which are relevant exactly for the beneficiaries of the financial statements. Consequently, the Standard was simplified as follows (E\&Y, 2010):

a) Subject matters irrelevant to small and middle-sized entities are left out;

Subject matters irrelevant to small and middle-sized entities are left out, so that issues regarding the scope of competence of IFRS 4 - Insurance contracts, IFRS 5 - Non-current assets held for sale, IFRS 8 - Operating segments: implementation guidance, IFRS 34 - Interim financial reporting - do not take part of the content of IFRS for SMEs;

b) In case of more then one option suggested by IFRS, only simpler option is adopted;

The complex options are left out: proportional consolidation, revaluation of plants, property and equipment, revaluation of intangible assets, government grants and assistance measured at fair value of the asset obtained or claimed, as opposed to IAS 20 - Accounting for government grants and disclosure of government assistance, which allows a series of different measurement methods.

Initial IFRS for SMEs issued in 2009 prescribe an accounting for the plants, property and equipment at a hystorical cost as for depreciation charge, as opposed to the large-scale standards, which tolerate the possibility of revaluation. However, one of the most important amendments to the standard in 2015. is that the Section 17 currently allows revaluation as a subsequent valuation method for the above-mentioned assets;

c) Recognition and measurement were simplified;

A series of simplifications include: less fair value for the agriculture, purchase value method for associated companies and joint ventures, value measurement can be based upon the directors deliberation on payments by shares.

Unlike the large-scale standards which differentiate 4 categories of financial instruments: financial asset or financial liability at fair value through the profit and loss statement (income statement); investments held until maturity, disposable loans (credits) and claims and financial assets, IFRS for 
SMEs differentiate 2 categories of financial instruments, as follows: basic financial instruments and other, complex financial instruments and transactions.

Therefore, questions on recognition and measurement of assets, liabilities, income and expense were simplified, and the use of fair value is reduced generally to a minimum and / or replaced with the hystorical cost principle;

d) Reduction of disclosure requirements;

Unlike so-called large-scale standards, which contain more than 3000 of items in the disclosure control list, IFRS for SMEs contain not more than 300 disclosure items, roughly a 90 per cent reduction (IASB, 2016).

Also, annual check of lifetime, residual value or depreciation method is not required neither for plant, property or equipment, nor for the intangible assets. The check is required only if there is a doubt that the significant amendments relative to the last reporting date took place.

The reduction of disclosure requirements is caused mainly by the following:

- Some IAS / IFRS are not comprised in the IFRS for SMEs (are left out);

- A certain principles and recognition and measurement methods are not tolerated in the IFRS for SMEs;

- Taking into account a relationship between costs and benefits as well as beneficiaries needs for financial statements.

Disclosure requirements are given in any Section of the International Financial Reporting Standards for Small and Medium-sized Entities, within any topic that the section refers to. Only in particular cases a disclosure is explicitly required in a financial report; in other cases it is not explicitly determined whether the disclosure should be given within financial statements or within explanatory notes.

A Compliance checklist for presentation and disclosure, accompanying the International Financial Reporting Standards for Small and Medium-sized Entities, prescribes a specific disclosure requirements derived from the Standards and contained in each Section. Disclosure requirements contained in the Compliance Checklist, that is to say IFRS for SMEs, are minimal. If additional disclosures are needed or the entity considers that there is a need for disclosing information which could be useful for beneficiaries, it is certainly obliged to disclose them (IASB, 2009).

According to the participants of financial reporting by small and mediumsized entities, based upon IFRS for SMEs, the most significant benefit is achieved through the reduction of disclosure requirements regarding information, which mostly contribute to simplified and more reliable financial reporting system, as well as the cost reduction. It is necessary to stress that 
reduced disclosure requirements in IFRS for SMEs do not cause decrease in quality nor completeness of financial reporting, but point to the obvious fact that so-called large-scale standards, or IAS / IFRS, are much too complex and extensive owing to the fact that they are designed to fit the needs and requirements of large-sized entities. Therefore, small and medium-sized entities do not have a need to meet the disclosure requirements designed for different accounting activities, transactions and categories, otherwise contained in IAS / IFRS.

On the other hand, although much more concise, the IFRS for SMEs takes into account some of the questions which are not stressed enough in the largescale standards, or IAS / IFRS, as follows (IASB, 2009):

- Consolidated financial statements (IFRS for SMEs: Section 9 Consolidated and Separate Financial Statements );

- The first issue of securities or other capital instruments (IFRS for SMEs: Section 22 - Liabilities and Equity);

- Selling of options, rights and warrants (IFRS for SMEs: Section 22 Liabilities and Equity );

- Capitalization or premium bonus securities and securities sharing (IFRS for SMEs: Section 22 Liabilities and Equity ).

The presentation of small and medium-sized entities financial statements is adjusted to the needs of beneficiaries and led by a cost reduction attempt in entities in a manner that the entity is not obliged to present a statement on a financial position of the earliest period comparable if it employs accounting policies retrospectively in financial statements or reclassifies items within financial statements, which is required in the IAS 1 - Presentation of Financial Statements.

Complete set of financial statements prepared on the basis of IFRS for SMEs compromises: Statement of financial position, Statement of comprehensive income and Income Statement, Statement of changes in equity, Statement of cash flows and Notes to the financial statements. IFRS for SMEs allows presentation of either: a single statement of comprehensive income which presents all items of income and expense in the period in the one statement; or two-statement approach: comprises an Income Statement including all items of income and expense recognised in the period except those recognised outside profit or loss; and a Statement of comprehensive income, which presents the items recognised outside profit or loss (PriceWaterhouseCoopers 2009). However, in the Republic of Serbia newly adopted Law on Accountancy (Official Gazette of Republic of Serbia, No. 62/2013) introduces the new financial statement which large, medium-sized and small entities are supposed (obliged) to prepare a Statement on other income, 
which presents items of income and expenses, non-recognized in income statement.

All deferred tax funds and liabilities are classified as fixed assets and longterm liabilities in the statement on financial position (balance sheet).

\section{International Financial Reporting Standard for Small and Medium-sized Entities and EU Accounting Directives}

Creation of international standards presupposes transperency and involvement of all the stakeholders and is a dynamic process that takes into account the importance and individual differences of each financial reporting system, by which, through continuous communication with the European Union authorities and regulatory bodies the international standards are constantly improved and harmonized with the best financial reporting practices, EU Directives and generally accepted accounting principles (GAAP).

After a detailed deliberation of the EU working group dealing with financial reporting in the European Union - European Financial Reporting Advisory Group (EFRAG) - six types of incongruences between IFRS for SMEs and EU Accounting Directives (EFRAG, 2010) are marked off. Reported incompatibilities between EU Directives and IFRS for SMEs are not a reason to doubt or worry since the EU Directives are subject to technical modifications whose completion was primarily projected for the end of 2013 and within which existing, slight differences between Directives and International standards were supposed to be harmonized. Besides, the European Union does not prescribe, but approves application of international standards by its members (Strouhal, 2010), since both standards and accounting directives are aimed at compatibility and standardization of global financial reporting.

Reported incompatibilities (EFRAG, 2010; SAAA, 2014) refer to:

a) Income and expense

The IFRS for SMEs contain an item classified as Other income and expenses, while EU Directive classifies the same activities as Extraordinary items. Obviously, in both cases items of income or expense are being referred to, concerning items which are not caused by the regular operating activities, so we can draw the conclusion that the incompatibility in question is of terminological nature.

b) Financial instruments at fair value

According to the IFRS for SMEs, all financial instruments at the end of the reporting period should be measured at fair value, and all related changes should be recognized in the income statement. However, there are exceptions, 
relating to capital instruments and certain type of contracts relating to such instruments. Some IFRS for SMEs approves withdrawal from fair value calculation if it causes unjustifiably high costs, compared to benefits (IASB, 2009).

EU Directives indicate purchase value as a principle of measurement for items at the end of a reporting period. EU Directives explain the concept of fair value, whereby EU legislature tolerates, but does not force obligatory assessment of financial instruments by applying fair value method in all entities. However, application of fair value assessment method, according to the EU Directives, is binding for the consolidated financial statements.

Therefore, the essential difference in financial statements assessment and measurement (in particular in assessment and measurement of financial obligations that are measured at fair value) refers to the fact that IFRS for SMEs require measurement at fair value for more elements than the Fourth EU Directive, currently the Directive 2013/34/EU, which indicates an alternative measurement at fair value with possibility that each member, for major part of financial instruments, approve or require application of the above-mentioned principle, in all or certain types of companies.

c) The useful life of Goodwill

The useful life of goodwill, according to IFRS for SMEs is 10 years, and in accordance with the EU Directive it is 5 years.

Newly adopted Directive 34/2013/EU prescribes that the useful life of goodwill cannot be estimated as a period shorter than 5 nor longer than 10 years.

d) Presenting unpaid capital as an offset to equity

IFRS for SMEs requires presenting of unpaid capital as an offset to equity, instead of presenting it as an item of asset. According to EU Directive, unpaid capital should be presented as an item of assets. According to the new Directive 2013/34/EU, unpaid capital should still be presented as an asset item in the balance sheet.

e) Reversal of goodwill impairment

According to IFRS for SMEs, an impairment loss recognized as a goodwill cannot be reversed in the following accounting period. According to EU Directive, it is necessary to abolish (reverse) goodwill impairment if the reasons due to which it has been recognized ceased to exist.

The EU Directive 34/2013/EU from the June 26, 20103, by whose enactment the Fourth Directive (78/660/EEC) as well as Seventh Directive (83/349/EEC) have been abolished, covers al the provisions regarding financial reporting for individual beneficiaries (Fourth Directive) and consolidated 
financial statements (Seventh Directive).

The newly adopted accountancy directive puts in the forefront the interests of small and medium-sized entities and aims to minimize requirements set for them. EU requests its members to harmonize their legislation and regulations with this Directive no later than July 20, 2015, which in the Republic of Serbia, as a candidate for membership, has not yet been accomplished.

\section{Implementation of International Financial Reporting Standard for Small and Medium-sized Entities in the Republic of Serbia}

The fact that the Law on Accounting and Audit (FRY Official Journal No. 71/2002) from 2002 has proscribed implementation of the IAS / IFRS in the Republic of Serbia, was a real breakthrough toward financial reporting standardization. The Serbian Association of Accountants and Auditors has created and published the Yugoslav Accounting Standards long before, during the 90-ies, and as well translated and published IAS / IFRS and other international professional regulation and has trained accountants for the implementation of the above-mentioned standards. Based on article 36 of the Law on Accounting, the Commission for Accounting has been established, bearing regulatory competence, which belongs to professional organizations, but without putting it into practice, which has been an obstacle on the way of financial reporting standardization. Nonetheless, standardization has been successfully performed up to the enactment of the new Law on Accounting in 2006, wherefore once achieved results and quality of financial reporting have been drastically impaired, primarily by formation of the Commission for Accounting and its unsuccessful work, which is best seen from the deletion of high range of its jurisdiction by the new, extremly bad Law on Accountancy (Stojanović, 2016; Malinić et al., 2016; Novićević, 2015; Malinić, 2015; Šević et al. 2013) from the year of 2013. and even worst subordinate legislation, which almost destroyed the proccess of standardization.

Contrary to the practice of EU membership, as well as of other EU candidates for membership, by the new Law on Accounting, a legislator in the Republic of Serbia, after more than 10 years of the IAS / IFRS implementation, has decided to bind more than $96 \%$ entities and direct them towards application of national rulebooks, as a set of unclear, incomplete rules deprived of any principle. An approach like that, instead of simple IFRS for large-sized entities or simplified IFRS for SMEs implementation in the Republic of Serbia has contributed to creating a state of confusion regarding financial reporting principles. The confusion has additionaly been complicated by the procedures applied on preparation of consolidated financial statements for the group of associated companies, whereby all alternative manners of preparation are 
possible (depending on the members size), as well as alternative preparation of consolidated financial statement (depending on the size of the group). In most cases it means that entities will be forced to keep double or even triple accounts and prepare several financial statement.

The current Law on Accounting (2013), instead of settling up plainly a financial reporting system within the real (as well as the public) sector, offers in fact the unluckiest regulational solutions, failing to recognize the interconnection between global and national professional regulation, with partial application of international standards, while creating several bases and alternatives to financial reporting (SAAA, 2015) which can be seen in the following illustration, No.1.

Graph 1: Review of the bases and alternatives of financial reporting according to the Law on Accounting

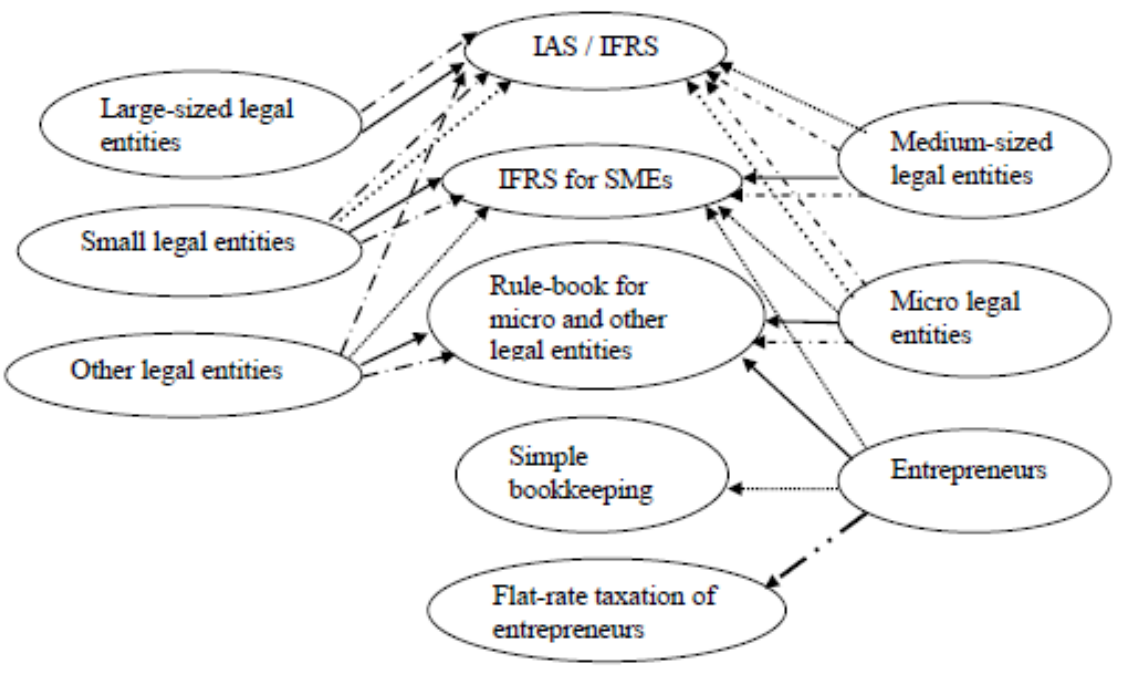

$$
\begin{aligned}
& \text { Mandatory application } \\
& \text { Possibility of choice } \\
& \text { For coinsólidation } \\
& \text { Mandatory application in } \\
& \text { certain cases } \\
& \text { For flat-rated entrepreneurs }
\end{aligned}
$$

Source: Adapted from SAAA (2015) The voice of accountants, 24/ 2015, p. 2 
Unadjusted regulatory solutions contained in the new Law on Accounting (RS Official Gazette No. 62/ 2013) as well as marking off the special reporting groups, micro-sized entities, designing particular reporting principles for them, with the lack of legal control or monitoring, as well as undefined status of the professional regulation and accounting profession or professional organizations - members of IFAC, are the main reasons for the poor quality of financial reporting in the Republic of Serbia which is not comparable to international practice where all global financial reporting standardization instruments are applied and accompanying professional regulation of IFAC is respected (Stojanović, 2016; Šević et al. 2016).

Considering the above indicated, obviously IFRS for SME implementation can help achieve:

- Improved quality of financial reporting by small and medium-sized entities;

- Financial statements comparability;

- Cost reductions - since it will not cause increased costs due to modifications in accounting software (or it will cause a slight increase in the costs of adjustment, but not necessarily), nor training for accountants shall be organized, since IFRS for SMEs implementation is a logical sequel to IAS / IFRS implementation which until now have already been implemented and adjusted to the entities. In that sense implementation of these standards should be supported and a proposal of the author of this paper is to enable medium-sized entities to choose whether to implement IAS / IFRS or IFRS for SMEs, under condition that it be designed by internal regulation of the proper entities;

Actually, there are medium-sized entities with a complex organization and a wide spectrum of business operations, which are striving to enlarge the scope of their activities, that is to transfigure from middle-sized to large-sized entities, and vice versa, so they have a possibility of choice, which is supported and allowed by the standards. Above-mentioned possibilities are considerably narrowed in the Republic of Serbia and the bylaws created are opposite to the Standards and EU Directives.

The translation and publication of the International Financial Reporting Standard for Small and Medium-sized Entities to Serbian was performed in 2009 and available for application in the entire Serbian language area - that is Serbia, Montenegro, Bosnia and Herzegovina, where IAS / IFRS are also applied, thanks to the collaboration of the Serbian Association of Accountants and Auditors, the Association of Accountants and Auditors of the Republika Srpska, and the Institute of Certified Accountants of Montenegro, which largely contributed to creation of a favourable ambient for the implementation of IFRS 
for SMEs. The possibility of choice between IAS / IFRS and the Rulebook adopted by the ministry of finance for small and medium-sized entities favors implementation of the IFRS for SMEs in the Republic of Serbia.

The majority of entities plead for the implementation of the IAS / IFRS, which means that by transition to IFRS for SMEs a financial reporting system will be improved, since this standard was created on the basis of IAS / IFRS and adjusted to smaller and less complex entities.

\section{Conclusion}

Considering above indicated advantages of the adoption and implementation of the International Financial Reporting Standard for Small and Medium-sized Entities (IFRS for SMEs) for the management and various stakeholders, the need for their implementation is obvious, through which these advantages could come into effect.

Since the new Law on Accounting prescribes the implementation of the IFRS for SMEs, except for the IFRS, but lacking in accompanying professional regulation, without recognizing the role of accounting profession and professional accountants and their associations, as it is in the modern society toward which Serbia is directed to, there seems to be a limit to the possibility of domestic financial statements standardization. This points to the need and a possibility to implement the IFRS for SMEs in the Republic of Serbia, inspired by experiences of the developed countries which are leaving their own standards and are implementing the global ones, as well as the accompanying professional regulation, generally accepted principles and procedures enacted by the global regulatory bodies. The author of this paper pleads for the abovementioned, since well-regulated financial reporting system means collaboration between the state, accounting profession and professional organizations, which determines national economies regulatory framework directed toward global market. To this end, the global standards, principles and procedures are created, whose implementation is in the best interest of national regulators and professional organizations responsible for their consistent implementation in practice.

Certainly, professional competence and ethical principles adopted by the professional accountants are crucial, as well as a willingness of an entity's management to standardize financial reporting.

Considering the current Law on Accounting, poor quality of bylaws and unclearly prescribed implementation of the IFRS for SMEs, as well as creation of Rulebook for micro-sized entities, other legal entities and entrepreneurs, and 
newly created Chart of Accounts for other legal entities ${ }^{3}$, it is obvious that the Law is not in the function of well-regulated financial reporting system nor financial reporting standardization.

Due to a disrespect of global and national professional regulations and the fact that the IFRS for SMEs, as for IAS / IFRS are published without the accompanying regulations, it is highly possible that domestic entities are implementing the standards arbitrarily and contrary to the international professional regulation and high quality financial reporting system. Instead of setting up unified financial reporting system, several bases for reporting and even more alternative possibilities and applicable charts of accounts have been introduced by the new Law on Accounting, by which a quality of financial reporting is significantly undermined and the costs of financial statements preparation are increased, which by no means can be of use to the Serbian economy.

The quality of current accounting regulation in the Republic of Serbia is poor and will leave permanent consequences on the financial reporting system. In order to improve the quality and standardization of financial reporting author suggests acceptance of the proposals and recommendations revealed at the $46^{\text {th }}$ Symposium by Serbian Association of Accountants and Auditors held on Zlatibor in May, published in the journal "Accounting " no. 2/2015, as a basis for the adoption of a new regulatory framework and the Law on Accountancy, as well as a new Law on Auditing.

\section{References}

Alver, L., Alver, J., Talpas, L. (2014) Implementation of IFRSs and IFRS for SMEs: the case of Estonia, Accounting and Management Information Systems, Vol. 13, No. 2, Tallinn University of Technology, Estonia, 236-258

Centre for Strategy and Evaluation Services (2010) The 4th Company Law Directive and IFRS for SMEs, Final Report, EU:EFRAG

EFRAG (2010) „Feedback Statement EFRAG's consultation on Compatibility Analysis: IFRS for SME and the EU Accounting Directives“, EU: European Financial Reporting Advisory Group, 2010.

EFRAG (2015) The EU endorsement status report Position as at 3 December 2015,

${ }^{3}$ Other legal entities - definition according to the article 2. par. 1. item 2. of the Law on Accounting: "By other legal entities we imply legal entities whose business operations are partly funded by public revenues or other allocated resources, and partly by membership fees and which are not profit-oriented (political organizations, syndical associations with characteristics of legal entity, foundations and endowments, associations, chambers, churches and religious comunities, partly perfoming economic or other activity according to regulations treating those activities, as well as other membership organizations).“ 
available online at:

http://www.efrag.org/files/Endorsement\%20status\%20report/EFRAG_Endorsem ent_Status_Report 4_September_2015.pdf (accessed in December 2015)

Ernst\&Young (2010) IFRS for small and medium-sized entities - A comparison with IFRS - the basics, available online at: http://www.ey.com/Publication/\%20vwLUAssets/IFRS for_SMEs_Comparison/\$ FILE/IFRS for SMEs Comparison.pdf (accessed in December 2015)

European Commision (2015) IAS Evaluation Report, available online at: http://ec.europa.eu/finance/accounting/ias-evaluation/index en.htm (accessed in December 2015)

European Parliament and the Council, Commission Directive 2013/34/EU of the European Parliament and of the Council of 26 June 2013 on the annual financial statements, consolidated financial statements and related statements of certain types of undertakings, Official Journal of the European Union L 182/19, 2013

IASB (2009) International Financial Reporting Standard for Small and Medium-Sized Entities - IFRS for SMEs - Basis for Conclusions, Illustrative financial Statements and Compliance Checklist for Presentation and Disclosure, UK: IFRS Foundation

IASB (2010) IFRS for SMEs - Project Update, IFRS Foundation

IASB (2013) A Guide for Micro-sized Entities Applying the IFRS for SMEs, UK: IFRS Foundation

IASB (2015) 2015 Amendments to the IFRS for SMEs, United Kingdom: IFAC

IASB (2016) A Guide to IFRS for SME, available online at: http://www.ifrs.org/IFRSfor-SMEs/Documents/A-guide-to-the-IFRS-forSMEs_March\%202016_Website.pdf

IFRS Foundation (2014) IFRS Fact Sheet, available online at: http://www.ifrs.org/IFRS-for-SMEs/Documents/Fact-Sheet/IFRS-for-SMEsFactsheet-August-2014.pdf (accessed in December 2015)

IFRS Foundation (2015) IFRS Application Around The World, Jurisdictional Profile: European Union available online at: http://www.ifrs.org/Use-around-theworld/Documents/Jurisdiction-profiles/European-Union-IFRS-Profile.pdf (accessed in December 2015)

Malinic, D. (2015) „Kritički osvrt na sadržinu i strukturu zvaničnih finansijskih izveštaja" (A critical review on the content and structure of official financial statements), 46th Symposium - Current issues and perspectives of accounting and finances,Belgrade, Serbian Association of Accountants and Auditors, 30-59

Malinić, D., Malinić, S., Novićević, B., Stojanović, R. (2016) Računovodstveni regulatorni okvir i kvalitet finansijskog izveštavanja u Republici Srbiji istraživačka studija, Belgrade: Serbian Association of Accountants and Auditors

Novićević, B. (2015) „Causes and consequences of poor-quality financial reporting in the Republic of Serbia“, 46th Symposium - Current issues and perspectives of accounting and finances, Zlatibor, Belgrade: Serbian Association of Accountants and Auditors, 7-29

Poljašević, J. (2011) „The impact of International Financial Reporting Standard for Small and Medium-sized Entities on financial performances of those entities", 15th Congress - Reflextions of International Financial Reporting Standards on accountancy, audit and business finances, Banja Luka: Association of Accountants and Auditors of the Republika Srpska, 101-126 
PriceWaterhouseCoopers (2009) IFRS for small and medium-sized entities, Pocket guide, available online at: https://www.pwc.com/gx/en/ifrsreporting/pdf/ifrssme09.pdf

Law on Accounting (2013) Official Gazette of Republic of Serbia, No. 62/2013

Law on Accounting and Audit (2002), Federative Republic of Yugoslavia Official Journal, No. 71/2002

Rulebook on manner in which items of individual financial statements of micro-sized and other legal entities are recognised, measured, presented and disclosed (2013) Official Gazette of Republic of Serbia, No. 118/2013

Rulebook on the manner in which assets, obligations, revenues and expenses of small legal entities and entrepreneurs are recognised and measured (2006) Republic of Yugoslavia Official Journal, No. 71/02 and RS Official Gazette, No. 106/2006 and and 111/2006

SAAA (2009) Practical implementation of IFRS in the Republic of Serbia: Belgrade, SAAA

SAAA (2014) "Aktuelna računovodstvena regulativa u Evropskoj uniji”, The voice of accountants No. 2/2014, Belgrade: SAAA

SAAA (2015) „Aktuelna računovodstvena regulativa u Republici Srbiji”, The voice of accountants No. 24/2015, Belgrade: SAAA

Skaric-Jovanovic, K. (2011) „Expectations and challenges the implementation of IFRS poses to small and medium-sized entities“, 15the Congress - Reflextions of International Financial Reporting Standards on accountancy, audit and business finances, Banja Luka: Association of Accountants and Auditors of the Republika Srpska, 15-38

Stojanović, R. (2015) „Ethics as an imperative for the effective application of fair value“, 46th Symposium - Current issues and perspectives of accounting and finances, Belgrade: SAAA, 83-108

Stojanović, R. (2016) „Divergencija računovodstvene regulative u Srbiji u odnosu na globalnu regulativu“, Računovodstvo No. 1, Belgrade: SAAA, 73-100

Strouhal, J. (2012) „Aplicability of IFRS for SMEs in the Czech Republic“, Economics and Management, 17(2), Kaunas University of Technology, Lithuania, 452-458.

Šević, Ž.; Škobić, Z. (2013) „Samoregulacija i javni nadzor u funkciji kvaliteta računovodstvene profesije“, Računovodstveno regulatorno okruženje: podsticaj ili ograničenje privrednog rasta, Belgrade, SAAA, 43-59

\section{RAČUNOVODSTVENA REGULATIVA FINANSIJSKOG IZVEŠTAVANJA ZA MALE I SREDNJE ENTITETE BEZ JAVNE ODGOVORNOSTI}

Apstrakt: Uspostavljanjem jedinstvenih pravila i principa za priznavanje i vrednovanje, prezentaciju i obelodanjivanje elemenata finansijskih izveštaja na globalnom novou obezbeđuje se uporedivost, harmonizacija i visok kvalitet finansijskog izveštavanja. Uzimajući u obzir jednostavnije zahteve malih i srednjih entiteta $u$ odnosu na velike entitete Odbor za međunarodne računovodstvene standarde (International Accounting Standards Board IASB) je kreirao standard finansijskog izveštavanja za srednje i male 
entitete bez javne odgovornosti, koji iako smanjenog obima i pojednostavljenih zahteva ne umanjuje kvalitet finansijskog izveštavanja. Autor u radu ima za cilj da ukaže na opravdanost potrebe za uspostavljanje standarda za srednje i male entitete, analizira njegove osnovne karakteristike i istraži odnose sa punim standardima i regulativom Evropske unije. Obavezna primena standarda za male i srednje entitete $u$ Republici Srbiji je opravdana, ali potrebni su i drugi uslovi kako bi se on uspešno implementirao, koji nisu obezbeđeni, jer je predviđena alternativna upotreba nacionalne regulative koja je nepotpuna i nedorečena, a uz to i nedosledna ovim standardima, zaključuje autor.

Ključne reči: finansijsko izveštavanje, standardizacija i kvalitet finansijskog izveštavanja, MSFI za MSE, računovodstvena regulativa, mali i srednji entiteti.

\section{Author's biography}

Tanja Škobić is a PhD student at the Faculty of Economics in Subotica. She graduated in 2009 from Faculty of Economics and Engineering Management, University of Business Academy, and received a MSc in Organisational Science in 2011 at the Faculty of Organisational Science, University of Belgrade. Started working at "ABC Global Financial Services Group" Ltd Belgrade, Accountancy and administration sector, to the year of 2012 when she started working in the State Audit Institution of the Republic of Serbia, the Sector for auditing financial statements of the National Bank of Serbia, public agencies and other public funds' beneficiaries. Until now, she has participated in a two-year project "Strengthening Capacities of the State Audit Institution of Serbia" in accordance with the Netherlands Court of Audit and the UK National Audit Office, other projects and conferences minding the audit of the central banks and few working groups. She has five published texts in the national and international professional papers. 